ANUVA Volume 2 (2): 233-242, 2018

Copyright (C2018, ISSN: 2598-3040 online

Available Online at: http://ejournal.undip.ac.id/index.php/anuva

\title{
Mewujudkan Fungsi Perpustakaan di Daerah
}

\author{
Ika Krismayani $^{1^{*}}$ \\ ${ }^{1}$ Program Studi Ilmu Perpustakaan, Fakultas Ilmu Budaya, Universitas Diponegoro \\ Jl. Prof. Soedarto, S.H, Kampus Undip, Tembalang, Semarang, Indonesia 50275 \\ *Korespondensi: ika.krismayani@live.undip.ac.id
}

\begin{abstract}
Library has five main functions are storage, education, research, information, and cultural recreation. These functions serve as a basis for performing daily tasks. The manifestation of the performance produced by librarians as the library manager. Building a library that still exists in the era of globalization is absolutely necessary so that the inherent function can be fulfilled. Some steps that can be applied are get near to the user, take control of technology and improvements in the librarian side. Therefore, as part of libraries, librarians should also always improve oneself.
\end{abstract}

Keyword: library function; regional library

\begin{abstract}
Abstrak
Perpustakaan memiliki lima fungsi pokok yaitu penyimpanan, pendidikan, penelitian, informasi, dan rekreasi kultural. Fungsi tersebut dijadikan dasar dalam melaksanakan tugas sehari-hari. Perwujudannya berupa kinerja yang dihasilkan oleh pustakawan selaku pengelola perpustakaan. Membangun perpustakaan yang tetap eksis di era globalisasi mutlak dilakukan agar fungsi yang melekat dapat terpenuhi. Beberapa langkah yang dapat diterapkan yaitu dengan mendekatkan diri dengan pemustaka, penguasaan teknologi serta pembenahan di sisi pustakawan. Oleh karena itu, sebagai bagian dari perpustakaan, pustakawan juga harus selalu berbenah.
\end{abstract}

Kata kunci: fungsi perpustakaan; perpustakaan daerah

\section{Pendahuluan}

Perpustakaan merupakan lembaga di mana masyarakat bisa mencari, berbagi, belajar, dan mengembangkan informasi yang mereka miliki. Melihat peran perpustakaan tersebut saat ini di beberapa daerah telah berdiri perpustakaan-perpustakaan. Beberapa di antara mereka menamakan dirinya taman bacaan dan beberapa lainnya tetap teguh dengan nama perpustakaan.

Masing-masing lembaga memiliki fungsi tersendiri. Fungsi inilah yang dijadikan dasar dalam melaksanakan tugas sehari-hari. Begitu juga dengan perpustakaan. Masing-masing perpustakaan memiliki fungsi yang berbeda berdasarkan jenis dan lembaga yang menaunginya. Meskipun demikian, perpustakaan, apapun jenis dan lembaga yang menaunginya, memiliki lima fungsi pokok yang sama yaitu penyimpanan, pendidikan, penelitian, informasi, dan rekreasi kultural (Qalyubi, 2003).

Perwujudan dari fungsi di atas berupa kinerja yang dihasilkan oleh pustakawan selaku pengelola perpustakaan. Dengan kata lain, tolok ukur profesionalisme pustakawan dapat dilihat dari kemampuan 
mereka untuk mewujudkan fungsi pokok tersebut. Perpustakaan dianggap berhasil jika mereka mampu melakukan kegiatan berupa menyimpan koleksi, menyediakan tempat belajar, mendukung proses penelitian, menyediakan informasi, dan menjadi tempat rekreasi.

\section{Fungsi Pokok Perpustakaan}

Setiap perpustakaan memiliki fungsi pokok yang sama. Lima fungsi tersebut meliputi penyimpanan, pendidikan, penelitian, informasi, dan rekreasi kultural (Qalyubi, 2003). Di bawah ini akan diuraikan kelima fungsi pokok tersebut.

1. Penyimpanan

Perpustakaan bertugas untuk menyimpan koleksi. Melalui fungsi ini, perpustakaan melakukan pengadaan koleksi untuk kemudian memelihara dan merawat koleksi yang telah mereka terima. Perpustakaan diharapkan dapat dijadikan sebagai lembaga yang mampu memelihara hasil pemikiran masyarakat di sekitarnya.

Selain melakukan penyimpanan koleksi, perpustakaan juga diharapkan mampu memiliki, menyediakan, dan memasarkan informasi yang dibutuhkan oleh pemustaka (Siess, 2003: 36). Di sini jelas bahwa perpustakaan tidak hanya bertugas untuk menyediakan koleksi, tetapi juga memasarkan koleksi yang ada di dalam perpustakaan. Tidak hanya itu, perpustakaan juga dituntut untuk dapat memberikan pengetahuan kepada pemustaka mengenai apa yang dapat mereka lakukan di perpustakaan.

Kegiatan pemasaran tidak hanya sebatas memperkenalkan koleksi, baik koleksi lama maupun koleksi baru kepada pemustaka. Tetapi juga memberikan pemahaman kepada pemustaka bahwa mereka dapat memperoleh suatu keuntungan dengan datang ke perpustakaan. Perpustakaan perlu dapat meyakinkan pemustaka, dengan datang ke perpustakaan, tidak hanya kebutuhan informasi yang terpenuhi, tetapi mereka juga akan mendapatkan hiburan, wawasan, dan lain-lain. Memberikan nilai tambah terhadap suatu informasi adalah tugas penting dari pustakawan.

\section{Pendidikan}

Pola dasar dalam mengartikan fungsi ini adalah bahwa perpustakaan merupakan tempat belajar sepanjang hayat bagi semua golongan masyarakat. Perwujudan dari fungsi ini lebih terlihat pada perpustakaan umum, khususnya perpustakaan umum daerah. Sebagai perpustakaan yang melayani seluruh lapisan masyarakat, perpustakaan umum dijadikan tempat belajar bagi seluruh masyarakat tanpa melihat tingkatan umur, status sosial, agama ataupun ras.

Sebagai tempat belajar sepanjang hayat, perpustakaan menyediakan tempat bagi mereka yang tidak dapat mengenyam pendidikan formal. Melalui penyediaan koleksi yang tepat, perpustakaan diharapkan mampu memberikan sarana untuk belajar bagi siapapun, kapanpun dan dimanapun. 
Selain itu, perpustakaan juga dituntut untuk mampu mengajarkan bagaimana informasi tersebut dapat diperoleh. Dalam hal ini, pustakawan perlu mendampingi pemustaka sekaligus memberikan jalan keluar terhadap kesulitan-kesulitan yang mereka temui dalam proses belajar-mengajar. Perpustakaan tidak hanya sebagai tempat belajar seumur hidup. Perpustakaan merupakan pendamping masyarakat dalam belajar.

3. Penelitian

Fungsi penelitian diartikan bahwa perpustakaan merupakan tempat untuk penelitian. Selain sebagai tempat belajar seumur hidup, perpustakaan harus mampu menjadi tempat untuk mendukung proses penelitian. Fungsi ini diwujudkan dengan menyediakan informasi yang diperlukan pemustaka dalam proses penelitian mereka.

Di sini terlihat bahwa pelaku penelitian adalah pemustaka. Dalam hal ini, perpustakaan diharapkan mampu menyediakan koleksi yang berhubungan dengan penelitian yang mereka lakukan. Koleksi yang erat kaitannya dengan kegiatan ini adalah koleksi jurnal ilmiah, artikel, dan kumpulan hasil penelitian.

Disamping sebagai tempat penelitian, perpustakaan, diakui atau tidak, perlu melakukan penelitian. Bentuk nyata dari fungsi ini adalah adanya kegiatan user study dalam proses kegiatan pengembangan koleksi. Proses pengadaan selayaknya diawali dengan mengetahui kebutuhan pemustaka. Hal ini bertujuan untuk meningkatkan relevansi antara kebutuhan dengan informasi yang tersedia.

Kegiatan penelitian tidak hanya terhenti dalam proses pengadaan. Perpustakaan juga harus mampu mencermati apa yang dibutuhkan pemustaka dan melakukan penelusuran dalam rangka memenuhi kebutuhan pemustaka. Proses penelusuran tidak hanya meliputi kegiatan pencarian informasi, tetapi menemukan metode yang tepat sehingga diperoleh tingkat akurasi hasil yang tinggi.

4. Informasi

Fungsi informasi merupakan fungsi terpenting dalam perpustakaan. Sebagai pusat informasi, perpustakaan harus mampu menyediakan informasi yang dibutuhkan oleh pemustaka. Kegiatan perpustakaan dikatakan berhasil jika informasi yang tersedia di perpustakaan sesuai dengan kebutuhan pemustaka. Hal ini menyebabkan perpustakaan menitikberatkan kegiatan mereka pada jumlah informasi yang tersedia, bukan pemanfaatan informasi itu sendiri. Akibatnya, banyak perpustakaan yang mengartikan pertumbuhan yang terjadi adalah adanya penambahan jumlah koleksi perpustakaan.

Perpustakaan tidak hanya menyediaakan informasi, tetapi juga dituntut untuk mampu menciptakan kemandirian dalam diri pemustaka. Hal inilah yang kemudian mendorong terwujudnya literasi informasi. Literasi informasi dapat diartikan sebagai kemampuan untuk mengidentifikasi, menemukan, mengevaluasi, mengorganisasi, dan menggunakan informasi (Prytherch, 2005: 351). 
Untuk mewujudkan fungsi ini, diperlukan adanya kerjasama yang baik antara pengelola perpustakaan dengan pemustaka. Kerjasama yang dilakukan dapat berupa komunikasi yang intens dalam proses pelayanan. Komunikasi tersebut diharapkan mampu memberikan pemahaman mengenai bagaimana memperlakukan informasi. Sehingga ke depan, perpustakaan akan mampu memberikan pelayanan dalam bentuk 'swalayan'. Pemustaka melayani diri mereka sendiri dalam proses pemenuhan kebutuhan informasi.

5. Rekreasi Kultural

Sebagian besar kalangan perpustakaan menganggap bahwa kata rekreasi berasal dari recreation yang dalam bahasa inggris berarti rekreasi atau hiburan. Dengan pengertian ini, dalam beberapa literatur perpustakaan, fungsi rekreasi diartikan sebagai rekreasi kultural yaitu perpustakaan menyediakan koleksi yang bertujuan agar masyarakat dapat membaca dan mengakses sumber informasi hiburan.

Pada kata recreation, perpustakaan dianggap telah berhasil menjalan fungsinya jika pemustaka telah mendapatkan informasi yang ringan dan bersifat menghibur sehingga mendapatkan kembali rasa segar, senang, dan rasa gembira baik dari segi jasmani maupun rohani. Dasar inilah yang dijadikan dasar perwujudan dari fungsi rekreasi perpustakaan.

Pada tahap ini, perpustakaan tidak hanya dituntut untuk mampu menghibur masyarakat pemustaka, tetapi juga diharapkan dapat mendorong munculnya karya-karya baru sehingga terjadi perkembangan ilmu pengetahuan di kalangan masyarakat yang dilayani. Kata rekreasi tidak dapat semata-mata diartikan sebagai penyediaan informasi ringan saja. Jika dikaji ulang, kata rekreasi merupakan perubahan dari kata recreation dalam bahasa Inggris. Selanjutnya, jika kata re diartikan sebagai kembali dan creation sebagai kreasi, maka kata tersebut memiliki arti kembali berkreasi.

Perubahan dari rekreasi menuju re-creation sangat erat kaitannya dalam rangka mewujudkan masyarakat informasi. Masyarakat informasi adalah masyarakat yang tidak hanya mengkonsumsi informasi, tetapi juga mampu menciptakan informasi bagi diri sendiri maupun orang lain. Pada fungsi re-creation, perpustakaan sebagai agen of change dituntut agar benar-benar dapat menciptakan perubahan. Perubahan mendasar yang akan terlihat adalah munculnya ilmu-ilmu baru, ide-ide segar yang akan dapat mengubah pola pikir dan kondisi sosial masyarakat sekitarnya.

\section{Tantangan Bagi Pustakawan}

Dalam bagian penjelasan, Undang-undang No. 43 Tahun 2007 tentang Perpustakaan disebutkan bahwa pemberlakuan sistem otonomi daerah telah memunculkan ketidakjelasan dalam hal kewenangan pusat dan daerah bidang perpustakaan. Dalam penjelasan tersebut disebutkan bahwa keberagaman kebijakan dalam pengembangan perpustakaan di daerah secara umum pada satu sisi menguntungkan sebagai pendelegasian kewenangan kepada daerah. Namun, di sisi lain dianggap kurang menguntungkan 
bagi penyelenggaraan perpustakaan yang andal dan profesional sesuai dengan standar ilmu perpustakaan dan informasi yang baku karena bervariasinya kemampuan manajemen dan finansial yang dimiliki oleh setiap daerah serta adanya perbedaan pemahaman dan persepsi

mengenai peran dan fungsi perpustakaan (Presiden Republik Indonesia, 2007:29).

Selanjutnya, kondisi tersebut memberikan tantangan bagi pustakawan untuk dapat mewujudkan fungsi-fungsi tersebut di atas. Perwujudan dari fungsi-fungsi tersebut tentunya akan berbeda di masingmasing daerah sesuai dengan kondisi dari masyarakat pemustaka yang mereka layani. Oleh karena itu, perlu beberapa strategi yang tepat untuk dapat mewujudkan beberapa fungsi tersebut. Di bawah ini akan dikemukakan beberapa strategi yang dapat dilakukan oleh para pengelola perpustakaan di daerah untuk dapat mewujudkan fungsi pokok perpustakaan.

\section{Bertahan pada Konvensional: Sebuah pilihan}

Di era teknologi seperti saat ini, seringkali kata 'konvensional' mendapatkan cibiran. Hal yang sama juga terjadi pada perpustakaan. Banyak sekali perpustakaan yang merasa bahwa diri mereka harus menerapkan teknologi informasi agar mampu bersaing dengan penyedia informasi lainnya. Anggapan ini tidaklah salah, tetapi juga tidak sepenuhnya benar.

Perpustakaan konvensional akan tetap mampu bertahan jika mereka mampu memberdayakan segala sumber daya yang ada. Perlu diketahui bahwa buku, sebagai salah satu sumber daya perpustakaan, tidak akan pernah tergusur dengan adanya sumber daya teknologi yang sedang berkembang di masyarakat. Sarjiyanto menyatakan bahwa berdasarkan hasil pengamatannya di perpustakaan menunjukkan bahwa pemustaka yang datang ke perpustakaan dengan membawa laptop dan mengakses internet tetap menggunakan buku sebagai bahan bacaan mereka (Sarjiyanto, 2011:41). Bahkan, menurut hemat penulis, jika penerapan teknologi hanya bertujuan untuk bersaing dengan lembaga lain, maka hal tersebut kurang dibenarkan.

Salah satu fungsi penerapan teknologi di perpustakaan adalah untuk mempermudah akses informasi, baik oleh pustakawan maupun pemustaka. Oleh karena itu, pustakawan terlebih dulu harus jeli dalam menentukan strategi penerapan teknnologi yang tepat sesuai kebutuhan perpustakaan. Jangan sampai, teknologi yang diterapkan ternyata tidak dibarengi dengan kesiapan pustakawan dan pemustaka yang dilayani.

Kembali ke masalah konvensional, pengelola perpustakaan konvensional tidak perlu merasa khawatir ketika memang memiliki keterbatasan sehingga belum mampu menerapkan teknologi di perpustakaan. Perpustakaan konvensional akan tetap bertahan jika mereka tetap mampu menjamin bahwa informasi akan selalu tersedia bagi pemustaka. Selain itu, perpustakaan konvensional harus mampu menjaga hubungan baik dengan pemustaka. Untuk itu, perpustakaan dapat mengambil langkah-langkah sebagai berikut.

1. Tetap terhubung dengan pemustaka. Ada pernyataan menarik yang diungkapkan oleh Napsha, seorang kepala perpustakaan umum di Michigan. Menurutnya, buku dan material lain di 
perpustakaan bukanlah hal terpenting di perpustakaan. Justru yang terpenting adalah adanya interaksi antar manusia di perpustakaan. Pengalaman di perpustakaan tidak hanya dilihat melalui transaksi yang terjadi melalui proses pinjam-meminjam di perpustakaan, tetapi lebih kepada bagaimana cara perpustakaan untuk dapat merangkul pemustaka agar tetap terhubung dengan perpustakaan (Hill, 2009: ix).

2. Penataan ruangan yang menarik. Saat ini, beberapa perpustakaan masih bertahan dengan warnawarna lama. Sebaiknya, perpustakaan mulai melihat warna-warna gedung yang sesuai dengan tren masa kini. Berdasarkan pengamatan penulis, saat ini, terdapat kecenderungan bagi masyarakat untuk memilih warna-warna yang cerah untuk tempat tinggal mereka. Kenapa hal ini tidak diikuti oleh perpustakaan? Warna-warna yang cerah diharapkan mampu membuat perpustakaan lebih menarik sehingga pemustaka merasa betah berlama-lama di perpustakaan.

3. Strategi 'jemput bola'. Strategi ini sebenarnya telah dilakukan sejak lama oleh pengelola perpustakaan umum dengan adanya perpustakaan keliling. Namun, pelayanan perpustakaan keliling saja tidak cukup. Perlu adanya kegiatan-kegiatan yang membuat perpustakaan terjun langsung ke lapangan seperti berperan serta dalam kegiatan ibu-ibu PKK, kelompok belajar bersama, dan lainlain.

4. Berproyeksi ke arah teknologi. Bagaimanapun juga, perpustakaan konvensional harus tetap berkembang. Mengingat perkembangan teknologi yang semakin pesat, maka sudah selayaknyalah perpustakaan mampu mengikuti perkembangan tersebut. Mungkin tidak untuk saat ini. Namun, tidak dapat dipungkiri bahwa pada saat ini, hampir semua perpustakaan telah memanfaatkan teknologi, meskipun dalam level yang paling minimum. Oleh karena itu, meskipun masih berkecimpung dengan hal-hal yang berbau konvensional, tetapi perpustakaan tetap harus mempersiapkan diri dengan perkembangan teknologi yang ada.

\section{Perpustakaan Digital: Sebuah harapan}

Derasnya arus informasi di era global akan berimbas pada kebutuhan informasi yang semakin meningkat. Masyarakat selanjutnya akan berusaha untuk memenuhi informasinya dengan cara yang mudah. Salah satu wujud usaha dari perpustakaan untuk menjawab kebutuhan tersebut adalah dengan menghadirkan perpustakaan digital.

Perpustakaan digital merupakan tempat penyimpanan koleksi referensi digital seperti jurnal elektronik dan database informasi (Stevenson dan Collin, 2006:57). Saffady dalam Saleh (2010:3) menyatakan bahwa perpustakaan digital merupakan perpustakaan yang mengelola semua atau sebagian yang substansi dari koleksi-koleksinya dalam bentuk komputerisasi sebagai bentuk alternatif, suplemen atau pelengkap terhadap cetakan konvensional dalam bentuk mikro material yang saat ini didominasi koleksi perpustakaan. Dengan demikian, berdasarkan pada definisi di atas, pada dasarnya perpustakaan digital tidak ubahnya seperti perpustakaan konvensional hanya saja memiliki kelebihan berupa adanya koleksi digital baik sebagian atau semuanya sebagai pelengkap dari perpustakaan konvensional itu sendiri. 
Topik mengenai perpustakaan digital masih tetap menjadi topik yang menarik untuk diperbincangkan. Saracevic dalam Pendit (2008:15) menyebutkan bahwa fenomena perpustakaan digital baru benar-benar hadir pada akhir 1990an. Baru setelah 10 tahun kemudian perpustakaan digital berada dalam tahap pengembangan. Melihat hal tersebut, maka perpustakaan digital sampai saat ini masih menjadi wacana yang baru berumur 20 tahun dalam dunia perpustakaan.

Wacana pembangunan perpustakaan digital di lingkungan perpustakaan terkadang masih menjadi perdebatan. Hal-hal yang menyangkut koleksi apa yang akan didigitalkan, siapa yang akan mengelolanya, dan berapa besar dana yang harus dikeluarkan. Cukup sulit memang ketika mengusung wacana perpustakaan digital tetapi masih dihadapkan pada masalah-masalah tersebut di atas.

Untuk mengatasi hal tersebut di atas, maka perpustakaan digital di lingkungan perpustakaan tidaklah harus serta-merta mengelola koleksi digital. Cukuplah perpustakaan digital yang memperbolehkan pemustaka untuk melakukan pinjam-meminjam menggunakan jaringan internet. Oleh karena itu, perpustakaan diharapkan mampu memberdayakan seluruh teknologi yang ada di sekitarnya.

Sebagai salah satu langkah untuk membangun perpustakaan tersebut di atas, pustakawan dapat menggunakan beragam aplikasi yang tersedia di internet, seperti Facebook misalnya. Salah satu dari aplikasi Facebook yang dapat dimanfaatkan untuk membangun perpustakaan adalah My Library. Program yang dikembangkan oleh Waleson, pemuda asal Midleburg, ini memungkinkan pustakawan untuk melakukan pinjam-meminjam koleksi perpustakaan. Dengan demikian, bagi perpustakaan yang belum memiliki perpustakaan online dalam arti yang sebenarnya, dapat memanfaatkan aplikasi My Library untuk mendekatkan pelayanan dengan pemustaka. Selain itu, dengan menggunakan sistem jaringan Facebook, aplikasi ini juga dapat dijadikan sebagai bentuk jaringan perpustakaan online sederhana.

Namun, pembangunan perpustakaan digital tidak boleh berhenti sampai pada tahap ini saja. Perpustakaan digital dalam arti yang sesungguhnya tetap harus menjadi perioritas di masa yang akan datang. Untuk itu, lagi-lagi dituntut kesiapan perpustakaan, baik pengelola maupun pemustaka. Pustakawan harus mampu menentukan bahwa kapan mereka akan memulai perpustakaan digital.

Pustakawan terlebih dahulu perlu menentukan koleksi apa yang akan mereka digitalkan. Perpustakaan digital akan dapat bertahan dan dikunjungi oleh pemustaka jika koleksi yang mereka miliki berbeda dengan perpustakaan digital yang lain. Pembangunan perpustakaan digital bukan berarti melakukn digitalisasi seluruh koleksi yang ada di perpustakaan. Oleh karena itu, pustakawan selayaknya terlebih dahulu memastikan bahwa koleksi digital yang mereka miliki tidak ditemukan di perpustakaan digital yang lain.

Hal lain yang perlu dipertimbangkan adalah menyediakan ruang komunikasi bagi publik di dunia digital. Pemusta tidak hanya diberi akses berupa baca ataupun download dokumen, tetapi juga diberi kesempatan untuk ikut berpartisipasi dalam mengolah dan mempromosikan koleksi. Bentuk pengolahan dapat berupa pemberian komentar, review, dan lain sebagainya. Fitur semacam ini sebenarnya sangat mudah untuk diciptakan, namun dalam praktiknya sangat sulit untuk diterapkan. Meskipun perpustakaan 
digital telah menyediakan fitur komentar bagi pemustaka, namun sangat jarang pemustaka yang bersedia memberikan komentarnya setelah mengakses koleksi digital. Oleh karena itu, dalam praktiknya, pemustaka terlebih dahulu dapat diberi hak untuk mengakses koleksi berupa baca koleksi, namun tidak diberi hak untuk mendownload atau mengkopi koleksi sebelum memberikan komentar mengenai koleksi yang telah mereka baca.

Hal terakhir yang perlu diperhatikan adalah kesiapan pemustaka sebagai pengguna perpustakaan digital. Sebelum memutuskan untuk memmbangun perpustakaan digital, maka sebaiknya perpustakaan terlebih dahulu memberikan pemahaman kepada pemustaka terhadap etika penggunaan perpustakaan digital. Dengan demikian, keberadaan perpustakaan digital akan mampu menjadi penopang bagi keberlangsungan perpustakaan di era globalisasi ini.

\section{Pembenahan Sisi Pustakawan}

Menurut Hernandono, berdasarkan pengalaman selama bekerja sebagai pustakawan, terdapat beberapa gejala aneh di dalam lingkungan kepustakawanan Indonesia, diantaranya sebagai berikut (Hernandono, 2005:7-10).

1. Sindrom autis. Sindrom autis adalah kecenderungan seseorang yang sibuk dengan dunianya sendiri, dan tidak suka bila ada orang lain mengganggu. Kondisi pustakawan Indonesia tidak ubahnya seperti penyandang autis. Hubungan emosional antara pustakawan dengan masyarakat masih sangat minim. Di samping itu, kemampuan adaptasi pustakawan terhadap hal-hal baru masih dipertanyakan.

2. Sebagian Pustakawan Indonesia masih lemah di dalam penguasaan bahasa asing dan teknologi informasi (TI). Kemampuan komunikasi adalah suatu hal yang penting dalam pemberian jasa layanan kepada pemustaka. Oleh karena itu, pengetahuan bahasa sebagai penopang dalam berkomunikasi harus dikuasai. Hal ini untuk mendorong kiprah pustakawan dalam kancah internasional. Di samping itu, pemahaman terhadap teknologi informasi juga dinilai masih minim. Banyak pustakawan yang masih belum menguasai teknologi komputer. Kondisi ini diperparah dengan penerapan teknologi tanpa disesuaikan dengan kebutuhan dan kemampuan masyarakat, baik pustakawan dan pemustaka.

3. Pada umumnya, sebagian Pustakawan tidak banyak menulis, apalagi dalam penulisan karya bersama. Tidak banyak pustakawan yang mampu dan mau menghasilkan karya tulis. Padahal, keberadaan karya tulis ini sangat penting sebagai media komunikasi dan pengenalan dunia perpustakaan kepada masyarakat. Kurangnya publisitas ini mengakibatkan profesi pustakawan mengalami perkembangan yang lambat dan semakin diabaikan oleh masyarakat.

4. Sebagian Pustakawan Indonesia sejauh ini bekerja sebagai burung dengan 'sebelah sayap'. Diibaratkan seperti burung, pustakawan adalah burung yang memiliki dua sayap yaitu egoisme pribadi, dan mengabaikan sayap yang lain yaitu kolaborasi dengan pustakawan yang lain. Kondisi ini mengakibatkan adanya ketimpangan kemajuan antara perpustakaan yang satu dengan perpustakaan 
yang lain. Hal ini semakin mempersulit proses integrasi pembentukan 'the universe library' yaitu suatu perpustakaan yang mampu merangkul seluruh kebutuhan pemustaka.

Keanehan tersebut di atas merupakan kelemahan-kelemahan yang telah teridentifikasi. Kelemahan tersebut harus segera diatasi jika perpustakaan ingin tetap eksis dalam dunia global. Beberapa langkah berikut ini dapat dilakukan dalam rangka menghadapi perubahan makna fungsi perpustakaan tersebut.

1. Menghilangkan sifat 'autisme' pustakawan. Pustakawan harus mampu bekerjasama dengan lembaga lain, bahkan lembaga yang berada di luar bidang perpustakaan. Kerjasama dengan profesi lain bukan semata-mata menghilangkan tugas inti pustakawan, yaitu mengeloa informasi. Kerjasama yang dilakukan adalah untuk mempermudah proses analisa informasi yang ada di kalangan masyarakat pemustaka. Hal ini perlu dilakukan karena tidak semua pustakawan memiliki pengetahuan yang menyeluruh mengenai berbagai disiplin ilmu. Oleh karena itu, kerjasama dengan profesi lain yang berbeda sangat diperlukan.

2. Pustakawan dan calon pustakawan hendaknya membekali dirinya dengan kompetensi sosial. Selama ini, pengetahuan yang dimiliki pustakawan adalah pengetahuan teknis di bidang perpustakaan. Kompetensi sosial yang dimaksud adalah kemampuan untuk bersosialisasi, pemecahan masalah, analisis informasi, dan bahkan, jika perlu pustakawan harus membekali dirinya dengan kemampuan enterpreneurship. Kemampuan-kemampuan tersebut sangat penting dalam rangka mewujudkan keberagaman pelayanan perpustakaan ke arah yang lebih baik.

3. Pustakawan harus visible. Selama ini pustakawan dikenal sebagai 'pekerja di balik layar'. Keberadaan profesi pustakawan masih jarang diketahi oleh masyarakat. Kondisi ini menyebabkan kurangnya pengakuan dari masyarakat terhadap profesi pustakawan itu sendiri. Oleh karena itu, pustakawan harus memberanikan diri untuk memulai langkah show up. Salah satu upaya dalam mem-visible-kan pustakawan adalah dengan muncul bersama kegiatan-kegiatan kreatif.

\section{Penutup}

Budaya globalisasi telah memutus keterbatasan yang ada. Membangun perpustakaan yang tetap eksis di era globalisasi beberapa langkah dapat diterapkan. Mulai dari mendekatkan diri dengan pemustaka. Kesemua wacana tersebut tidak akan dapat terwujud jika tidak diikuti dengan pembenahan di sisi pustakawan. Oleh karena itu, sebagai bagian dari perpustakaan, pustakawan juga harus selalu berbenah. Pustakawan juga harus membekali diri mereka dengan kreatifitas sehingga mampu menghasilkan sesuatu yang baru yang dapat menopang kebertahanan perpustakaan di tengah arus globalisasi yang ada. 


\section{Daftar Pustaka}

Hernandono. 2005. "Meretas kebuntuan kepustakawanan Indonesia dilihat dari sisi sumberdaya tenaga perpustakaan". Orasi Ilmiah dan Pengukuhan Pustakawan Utama Tahun 2005

Hill, Crhisty. 2009. Inside, Outside, and Online: Building your library community. Chicago: Amerin Library Association.

Pendit, Putu Laxman. 2008. "Perpustakaan Digital Perguruan Tinggi : tantangan peningkatan kualitas jasa". Makalah disampaikan pada Workshop Manajemen Perpustakaan Perguruan Tinggi "Meningkatkan Citra Perpustakaan Guna Membangun Strategi Keunggulan Bersaing", 25 November 2008, Hotel Santika Premiere Semarang.

Prytherch, Ray. 2005. Harrod's Librarians' Glossary and Reference Book: A directory of over 10,200 terms, organizations, projects and acronyms in the areas of information management, library science, publishing and archive management. England: Ashgat.

Presiden Indonesia. 2007. "Undang-undang No. 43 Tahun 2007 tentang Perpustakaan" dalam http://www.pu.go.id/satminkal/itjen/peraturan/UU_43_2007_PERPUSTAKAAN.pdf / diakses pada 16 Juni 2012 pukul 23:03 WIB.

Qalyubi, Syihabuddin, dkk. 2003. Dasar-dasar Ilmu Perpustakaan dan Informasi. Yogyakarta: Jurusan Ilmu Perpustakaan dan Informasi Fakultas Adab UIN Sunan Kalijaga Yogyakarta.

Saleh, Abdul Rahman. 2010. Membangun Perpustakaan Digital: Step by step. Jakarta: Sagung Seto.

Sarjiyanto, Anang. 2011. “Akankah Perpustakaan Konvensional Tergusur Perpustakaan Digital” dalam Sangkakala Edisi Kesepuluh tahun 2011.

Siess, Judith A. 2003. The Visible Librarian: Asserting your value with marketing and advocacy. Chicago: American Library Association.

Stevenson, Janet dan P. H. Collin. 2006. Dictinary of Information and Library Management. London: A \& C Black.

Tim Penyusun Kamus Pusat Bahasa. 2008. Kamus Bahasa Indonesia. Jakarta: Pusat Bahasa.

Winarko, Bambang. 2009. "Perpustakaan Digital di Indonesia dan Fitur-Fitur yang Tersedia". Dalam Jurnal Perpustakaan Pertanian Vol. 18, Nomor 2, 2009. 